\title{
Magda URBAŃSKA*
}

\section{MEDIACJE I ICH WYKORZYSTANIE W PRACY SOCJALNEJ Z RODZINA}

\begin{abstract}
Streszczenie
Mediacje sa procesem, w trakcie którego skonfliktowane strony, przy pomocy bezstronnego i neutralnego mediatora wypracowuja wzajemnie je satysfakcjonujace porozumienie. Mediacje wykorzystywane sq w różnych obszarach spraw rodzinnych, gospodarczych, cywilnych, karnych. Moga być także prowadzone $w$ obszarze pomocy społecznej $i$ wykorzystywane w pracy socjalnej jako sposób rozwiązywania konfliktów klientów pomocy społecznej. Ustawa o wspieraniu rodziny i systemie pieczy zastępczej wymienia mediacje jako jedna z form wsparcia rodziny przeżywającej trudności w wypetnianiu funkcji opiekuńczo-wychowawczych. Szczególnie przydatne wydaje się stosowanie mediacji w sytuacji konfliktów rodzinnych klientów, gdzie przy wsparciu pracownika socjalnego w roli mediatora strony moga nie tylko wypracować obopólnie korzystne porozumienie, ale także podtrzymać lub odbudować relacje rodzinne. W artykule omówiono pojęcie mediacji, jej rodzaje a także możliwości ich wykorzystania w kontekście pracy socjalnej. Zaprezentowano procedure postepowania mediacyjnego $w$ pracy socjalnej oraz korzyści i trudności związane z mediacja jako metoda pracy z klientami pomocy społecznej.
\end{abstract}

Stowa kluczowe: mediacje, praca socjalna, mediacje socjalne

* Dr Magda Urbańska - socjolog, adiunkt w Katedrze Nauk o Rodzinie Wydziału Pedagogicznego Uniwersytetu Rzeszowskiego, mediator w sprawach cywilnych. 


\section{Wprowadzenie}

Mediacje wykorzystywane są w sytuacji konfliktów, które pojawiają się w różnych obszarach funkcjonowania człowieka. Ich istotą jest wsparcie skonfliktowanych stron przez bezstronnego i neutralnego mediatora, który pomaga im w wypracowaniu obustronnie korzystnego porozumienia. Mediacje są dobrowolne i poufne. Opierają się na współpracy w poszukiwaniu wspólnego rozwiązania sytuacji problemowej, a ostateczny kształt porozumienia zależy wyłącznie od wspólnych ustaleń stron. Mediator, zgodnie z zasadą bezstronności i neutralności, nie proponuje żadnych rozwiązań. Nie jest jego rolą także rozstrzyganie sporu, ocena czy doradzanie, a jedynie wsparcie stron w procesie wzajemnej komunikacji. Celem mediacji jest uzyskanie świadomego i wzajemnie satysfakcjonującego porozumienia, które uwzględnia obopólne interesy stron. Zatem wszędzie tam, gdzie pojawia się gotowość stron konfliktu do zawarcia ugody otwiera się pole do mediacji.

Konflikty i spory nie omijają także klientów pomocy społecznej. Trudna sytuacja życiowa wielu rodzin, które są podopiecznymi instytucji pomocowych wynikająca m.in. z bezrobocia, ubóstwa, czy niepełnosprawności sprzyja spiętrzeniu problemów i powstawaniu różnorodnych sytuacji konfliktowych. Jednym ze sposobów ich rozwiązywania są mediacje, które uczyniono przedmiotem rozważań podjętych w niniejszym artykule. Mediacje mogą być traktowane jako narzędzie w pracy socjalnej, bowiem korzyści uzyskiwane przez klientów pomocy społecznej podczas mediacji przyczyniają się pośrednio do realizacji celu pracy socjalnej - rozwinięcia lub wzmocnienia aktywności i samodzielności życiowej podopiecznych ${ }^{1}$. Mediacja przełamuje bierność i pozwala przezwyciężyć bezradność. Sprzyja za to kreatywności klientów pomocy społecznej w poszukiwaniu wspólnych rozwiązań konfliktu, równocześnie wymagając zaangażowanego uczestnictwa. Efektem mediacji może być także wzmocnienie klienta, związane ze wzrostem poczucia własnej wartości i kontroli nad życiem ${ }^{2}$. Korzyści z zastosowania mediacji w pracy socjalnej znajdują praktyczne potwierdzenie stwierdzenia, że „to nie konflikt jest źródłem nieporozumień i walki między ludźmi, lecz sposób jego rozstrzygania”’3.

\footnotetext{
1 Art. 45.1 pkt. 1 Ustawa z dnia 12 marca 2004 r. o pomocy społecznej (Dz.U. 2004, nr 64, poz. 593).

2 B. Dubois, K.K. Miley, Praca socjalna. Zawód, który dodaje sit, t.1, tł. K. Czekaj, Interart, Warszawa 1996, s. 141.

A.W. Nocuń, J. Szmagalski, Podstawowe umiejętności w pracy socjalnej i ich ksztatcenie. Porozumiewanie się, rozwiązywanie problemów i konfliktów, Śląsk, Katowice 1998, s. 119.
} 
Celem artykułu jest ukazanie mediacji jako ugodowego sposobu rozwiązywania konfliktów w kontekście możliwości jej wykorzystania przez służby pomocy społecznej w pracy socjalnej z rodziną.

\section{Mediacja - terminologia}

Mediacje należą do grupy pozasądowych metod rozwiązywania sporów, zwanych w skrócie ADR (ang. alternative dispute resolution). Ich główną ideą jest odejście od konfrontacyjnego sposobu działania, połączone z koncentracją na rozwiązaniu problemu a nie na walce $\mathrm{z}$ drugą stroną konfliktu. ADR cechują się udziałem bezstronnej osoby trzeciej, która nie rozstrzyga sporu oraz brakiem formalizmu, pierwszeństwem interesów stron przed dogmatyką prawną a także bezpośrednim udziałem stron i ich konstruktywnym współdziałaniem ${ }^{4}$. W tej grupie, oprócz mediacji, znajdują się także negocjacje, koncyliacje, arbitraż i miniproces ${ }^{5}$. W literaturze przedmiotu mediacje nie mają jednej definicji. Rafał Morek wskazuje na dwie koncepcje definicyjne: w szerokim znaczeniu mediacje to pojęcie zbiorcze, które odnosi się do niejednorodnych postępowań o różnych nazwach, których celem jest pojednawcze rozwiązanie sporu przy pomocy osoby trzeciej. W wąskim rozumieniu mediacja wiąże się z jej podstawowymi cechami, do których należą dobrowolność i pozasądowy charakter ${ }^{6}$.

Literatura przedmiotu podaje zatem wiele definicji mediacji, $w$ dużej mierze skupiających się na zasadach obowiązujących w mediacji lub jej celu np. mediacja jest „,formą rozwiązywania sporów opierającą się na wyspecjalizowanej niewładczej ingerencji osoby trzeciej, bezstronnej i neutralnej wobec stron i ich konfliktu”; to „dobrowolny i poufny proces dochodzenia do rozwiązania sporu, prowadzony w obecności osoby neutralnej, czyli mediatora”, „negocjacja we troje, w której trzecia neutralna strona jest moderatorem w procesie wyjaśniania spornych

4 R. Morek, Wprowadzenie, w: Mediacje. Teoria i praktyka, red. E. Gmurzyńska, R. Morek, Wolters Kluwer Polska Sp. z o.o., Warszawa 2009, s. 22.

5 Tamże, s. 22; K. Bargiel-Matusiewicz, Negocjacje i mediacje, Polskie Wydawnictwo Ekonomiczne, Warszawa 2010, s. 88; H. Duszka-Jakimko, Alternatywne rozwiazywanie sporów prawnych na tle rozwojowego modelu prawa, w: Wokót praktycznych i teoretycznych aspektów komunikacji, red. P. Malinowski, H. Duszka-Jakimko, A. Suchorska, Uniwersytet Opolski, Kraków 2015, s. 12-15.

6 R. Morek, Wprowadzenie, dz. cyt., s. 16.

7 A. Kalisz, A. Zienkiewicz, Mediacja sadowa i pozasadowa. Zarys wykładu, Wolters Kluwer Polska Sp. z o.o., Warszawa 2009, s. 43.

$8 \quad$ K. Bargiel-Matusiewicz, Negocjacje..., dz. cyt., s. 89. 
kwestii przez negocjatorów, pomocnikiem w szukaniu przez nich obustronnie satysfakcjonującego rozwiązania konfliktu, a przeciwstawianiu się dążeniom typu 'wygrany-przegrany”", ,dobrowolne, poufne i niesformalizowane pozasądowe postępowanie w sprawach, w których możliwe jest zawarcie ugody, prowadzone między stronami (uczestnikami) określonego sporu przez osobę trzecią - bezstronnego mediatora celem doprowadzenia do ugodowego załatwienia tego sporu"10.

Mediacje można podzielić na mediacje sądowe, odbywające się ze skierowania sądu oraz mediacje umowne, pozasądowe, będące efektem inicjatywy stron konfliktu. $Z$ punktu widzenia roli mediatora i jego udziału w wypracowaniu porozumieniu a także celu mediacji wyróżnia się mediację:

- facylitatywną, zwaną mediacją klasyczną, opierającą się na przekonaniu, że to strony, przy pomocy osoby neutralnej, współpracują ze sobą, samodzielnie dochodząc do rozwiązania konfliktu. Mediator pomaga stronom w dojściu do ugody, bazując na rozwiązaniach proponowanych przez uczestników mediacji. Sam nie sugeruje żadnych sposobów rozwiązania sporu, nie dokonuje również oceny sytuacji faktycznej i prawnej;

- ewaluatywną, zwaną ocenną - w tym rodzaju mediacji mediator nie ogranicza się do wsparcia stron w wypracowaniu rozwiązania. Może sam proponować sposoby rozwiązania sporu, pomagać stronom w ocenie słabych i mocnych aspektów ich sprawy, sytuacji prawnej, przewiduje ewentualne rozstrzygnięcie sądu. Mediator pełni rolę eksperta nie tylko w zakresie sposobu rozwiązania sporu, ale także w określonej dziedzinie, co pozwala mu na specjalistyczną ocenę sytuacji stron. Mediacje tego typu wzbudzają wiele kontrowersji;

- mediację opartą na interesach stron, nazywaną mediacją koncentrującą się na rozwiązaniu sporu - konflikt definiowany jest tutaj jako problem do rozwiązania, a celem negocjacji stron jest przejście z pozycji (stanowisk stron) do interesów (potrzeb stron). Mediator pomaga stronom w dojściu do istoty problemu i określeniu kwestii do rozwiązania, które stają się punktem wyjścia do negocjowania rozwiązania. Celem mediacji jest osiągnięcie wspólnie akceptowalnego rozwiązania konkretnego sporu, a celem mediatora pomoc w jego wypracowaniu;

9 A. Pietrzyk, Praca w zespole. Rozwiązywanie problemów i konfliktów grupowych, w: Praca socjalna wobec współczesnych problemów społecznych, red. S. Pawlas-Czyż, Wydawnictwo Edukacyjne Akapit, Toruń 2007, s. 25-26.

10 A. Rękas, Czy tylko sąd rozstrzygnie w sporze? Mediacja i sądownictwo polubowne, Ministerstwo Sprawiedliwości, Warszawa 2010, s. 19. 
- mediację transformatywną - celem tych mediacji jest zmiana charakteru relacji wynikających z konfliktu. Zwraca się tutaj uwagę przede wszystkim na wzmocnienie stron i wzajemne zrozumienie, możliwość moralnego rozwoju i zmianę podejścia do problemów, niekoniecznie przejawiające się wypracowaniem sposobu zakończenia sporu;

- mediację narratywną - podejście opierające się na założeniu, że większość konfliktów jest następstwem użycia określonego języka a nie faktycznych sytuacji. Celem tej mediacji jest zbudowanie, przy pomocy mediatora, nowej opowieści o konflikcie, która ma bardziej pozytywny wydźwięk, co może być przydatne w rozwiązaniu nie tylko obecnego sporu, ale także sporów pojawiających się w przyszłości;

- mediację humanistyczną - podejście, w którym najważniejszym celem mediacji jest uzdrowienie relacji, opiera się przede wszystkim na dialogu mediatora i stron ${ }^{11}$.

Głównym celem mediacji jest spisanie ugody lub porozumienia, które jest akceptowane przez obie strony. Warto jednak w tym miejscu podkreślić także pośrednie cele mediacji, które mogą, choć nie muszą, być realizowane przy okazji mediacji. Agnieszka Lewicka-Zelent ukazuje je w kontekście aspektu komunikacyjnego, społecznego, w wymiarze indywidualnym oraz prawnym. W aspekcie komunikacyjnym mediacja to przede wszystkim szansa na poprawę relacji między skonfliktowanymi stronami, co związane jest ze sposobem prowadzeniem rozmowy zgodnej z zasadami konstruktywnego dialogu, wolnego od przemocy. $\mathrm{W}$ aspekcie społecznym mediacja przeciwdziała eskalacji konfliktu, co pozwala na ograniczenie strat w różnych wymiarach życia ludzi pozostających w konflikcie oraz osób, które byłyby zaangażowane w konflikt w wyniku jego natężenia. Porozumienie na drodze mediacji zwiększa także świadomość prawną społeczeństwa oraz korzyści, także w perspektywie przyszłych sytuacji problemowych, związanych z polubownym rozwiązaniem sporu. W wyniku mediacji zmiany mogą zachodzić także w samych uczestnikach postępowania mediacyjnego, w ich sferze psychicznej i emocjonalnej. Wiąże się to z zaspokojeniem, w równym stopniu, potrzeb obu stron konfliktu. Mediacja to zatem także nauka świadomego podejmowania decyzji, asertywności, tolerancji i empatii, ale także wiary we własne siły,

11 E. Gmurzyńska, Rodzaje mediacji, w: Mediacje. Teoria i praktyka, 2. wydanie rozszerzone, red. E. Gmurzyńska, R. Morek, Wolters Kluwer Polska Sp. z o.o., Warszawa 2014, s. 176-187. 
samoświadomości i współpracy. W ostatnim z przywołanych aspektów mediacja umożliwia skrócenie czasu postępowania przed sądem ${ }^{12}$.

Mediacje mogą być prowadzone w sprawach cywilnych, w tym rodzinnych, gospodarczych, z zakresu prawa pracy a także w sprawach karnych osób dorosłych i nieletnich. Coraz częściej stosowane są w środowisku szkolnym w postaci np. mediacji rówieśniczych. Polem zastosowania mediacji staje się także obszar pomocy społecznej i pracy socjalnej. W literaturze przedmiotu określa się je mianem „mediacji socjalnych”, „,mediacji w pracy socjalnej”, ,mediacji w pomocy społecznej”"13. Agnieszka Lewicka-Zelent przypuszcza, że w instytucjach pomocy społecznej będzie potrzeba częstszego korzystania z mediacji rodzinnych, ze względu na to, iż większość konfliktów, których doświadczają klienci pomocy społecznej to problemy rodzinne ${ }^{14}$. Autorka zauważa, że pracownicy socjalni mogą brać udział zarówno w formalnych mediacjach, uregulowanych prawnie, jak i mediacjach nieformalnych. Zadaniem pracowników socjalnych jest także przekazywanie klientom pomocy społecznej wiedzy o mediacji, co może sprzyjać podjęciu przez nich próby rozwiązania sporu przy pomocy osoby trzeciej ${ }^{15}$. W świetle Ustawy o wspieraniu rodziny i systemie pieczy zastępczej mediacja to jedna $\mathrm{z}$ form wsparcia rodziny, kierowana do rodzin przeżywających trudności w wypełnianiu funkcji opiekuńczo-wychowawczych ${ }^{16}$. Mediacje rodzinne najczęściej dotyczą spraw rodzinnych i rozwodowych oraz spraw związanych z podziałem majątku i opieką nad dziećmi po rozwodzie. Przedmiotem mediacji mogą być także zasady współpracy rodziny biologicznej z rodziną zastępczą lub biologiczną, konflikty sąsiedzkie, sprawy karne osób dorosłych i nieletnich, sprawy gospodarcze i cywilne ${ }^{17}$.

12 A. Lewicka-Zelent, Mediacja - podstawy teoretyczne, w: E. Grudziewska, A. Lewicka-Zelent, Kompetencje mediacyjne w profesji pracownika socjalnego, Difin SA, Warszawa 2015, s. 28-30.

13 P. Bunio-Mroczek, Rodzaje mediacji i ich rola w pracy socjalnej, „Zeszyty Pracy Socjalnej" 2016, z. 1, s. 12.

14 A. Lewicka-Zelent, Mediacja..., dz. cyt., s. 35.

15 Tamże, s. 32-36.

16 Art. 10.3 pkt. 2 Ustawa z dnia 9 czerwca 2011 r. o wspieraniu rodziny i systemie pieczy zastępczej (Dz. U. 2011, nr 149, poz. 887).

17 Regionalny Ośrodek Polityki Społecznej w Krakowie, System wspierania i formy pracy z rodzina, Kraków 2013, s. 16-17. 


\section{Mediacje w pracy socjalnej}

Mediacje w pracy socjalnej rozumiane są jako pośredniczenie w rozwiązywaniu konfliktu, w którym stroną lub stronami są klienci pomocy społecznej ${ }^{18}$. Aleksander Nocuń i Jerzy Szmagalski odnosząc się do mediacji w kontekście pracy socjalnej, definiują to pojęcie w znaczeniu szerokim i wąskim, zaznaczając równocześnie, że w codziennej praktyce pracy socjalnej bardziej przydatne jest ujęcie drugie. W ujęciu szerokim utożsamiają oni mediację z podstawową funkcją pracy socjalnej. W ujęciu wąskim mediacja to „technika rozwiązywania konfliktów interpersonalnych, zapewniająca neutralne forum, na którym skonfliktowane strony otrzymują pomoc $\mathrm{w}$ znalezieniu wzajemnie zadowalającego rozwiązania powstałej między nimi sprzeczności"19. Za S. Chandlerem wskazują, że mediacja związana jest z uczestnictwem dwu stron w konflikcie, jest procesem krótkotrwałym i zorientowanym na rozwiązywanie określonych problemów ${ }^{20}$. Celem mediacji w pracy socjalnej jest wypracowanie porozumienia, które satysfakcjonuje obie skonfliktowane strony i respektuje ich interesy. To porozumienie typu ,wygrany-wygrany" a nie ,wygrany-przegrany”21.

Według Aleksandra Nocunia i Jerzego Szmagalskiego mediacja w pracy socjalnej jest techniką, która wspomaga klientów w usprawnianiu lub odzyskiwaniu zdolności do satysfakcjonującego funkcjonowania w środowisku społecznym. Cechą wspólną mediacji z innymi technikami pracy socjalnej jest rozwiązywanie problemów, gdyż konflikty są pewnym rodzajem problemów, utrudniającymi ludziom dążenie do swoich celów ${ }^{22}$. Mediacje są wpisane w pracę socjalną, gdyż wspomagają bliskość, poprawiają jakość życia rodzinnego klientów, oferują możliwość rozwoju osobistego oraz upodmiotowiają klientów ${ }^{23}$.

Odnosząc się do mediacji w kontekście pracy socjalnej warto zwrócić uwagę, że pracownik socjalny może występować tutaj w trzech rolach: osoby prowadzącej formalne mediacje jako certyfikowany mediator bądź w roli nieformalnego mediatora, wykorzystującego umiejętności mediacyjne w pracy socjalnej z klientem, osoby kierującej klientów do mediacji oraz osoby, która jest stroną w mediacji np.

18 I. Podobas, Mediacje i negocjacje w pracy socjalnej, Centrum Rozwoju Zasobów Ludzkich, Warszawa 2014, s. 158.

19 A.W. Nocuń, J. Szmagalski, Podstawowe..., dz. cyt. s. 175, 182.

20 Tamże, s. 182-183.

21 I. Podobas, Mediacje..., dz. cyt., s. 75-77.

22 A.W. Nocuń, J. Szmagalski, Podstawowe..., dz. cyt., s. 183.

23 P. Bunio-Mroczek, Rodzaje..., s. 20. 
w konflikcie z klientem, współpracownikiem czy pracodawcą ${ }^{24}$. Pracownicy socjalni prowadzący mediacje mogą czynić to na prośbę stron, które są w sporze lub też mogą występować z urzędu jako przedstawiciele ośrodka pomocy społecznej. Mogą także podjąć się mediacji nieformalnej i zaproponować stronom, z uwzględnieniem zasady dobrowolności uczestnictwa, rozmowę o możliwych sposobach rozwiązania sporu. W sytuacji, gdy klient pomocy społecznej tego potrzebuje, pracownik socjalny może także podjąć się mediacji przed innymi instytucjami np. kuratorem, pedagogiem szkolnym ${ }^{25}$.

Jak wskazują Dorota Rynkowska i Małgorzata Artymiak warunkiem prowadzenia mediacji przez pracownika socjalnego jest jego akceptacja przez obie strony konfliktu. Mediacja, jako działanie podejmowane przez pracownika socjalnego na rzecz klienta, polega na pośrednictwie w sporze i pełnieniu roli doradcy. Autorki nazywają ją krótkotrwałym procesem $\mathrm{w}$ rodzinnym poradnictwie socjalnym o charakterze działań planowych, które opierają się na zasadach sprawiedliwości i uczciwości przy respektowaniu praw każdej ze stron. Pracownik socjalny w roli mediatora próbuje zatem wypracować wspólną płaszczyznę porozumienia, określić istotę konfliktu a także wesprzeć strony w znalezieniu rozwiązania problemu. Równocześnie mediacja prowadzona przez pracownika socjalnego to pośrednia realizacja metody pracy z przypadkiem, zmierzająca do takiego rozwiązania konfliktu, które będzie satysfakcjonowało obie strony ${ }^{26}$.

Mediacja w pracy socjalnej ma swoją procedurę. Obejmuje pięć etapów postępowania mediacyjnego, na które składają się: 1) rozpoczęcie mediacji, obejmujące rozpoznanie przez mediatora spraw istotnych dla stron, ich stosunku względem siebie oraz gotowości do podjęcia mediacji. Etap ten wiąże się także z uzyskaniem zgody stron na przeprowadzenie mediacji i dobrowolnego do nich przystąpienia przez obie strony, akceptacji mediatora oraz przedstawieniem stronom podstawowych zasad mediacji, 2) definicja konfliktu - na tym etapie strony, przy pomocy mediatora, określają obszary zgody i niezgody. Może się to odbywać także w formie indywidualnych spotkań ze stronami, 3) negocjacje stron ze wsparciem mediatora - na tym etapie następuje kolejno ustalenie reguł postępowania, zdefiniowanie wspólnych i sprzecznych interesów każdej ze stron, zdefiniowanie problemów oraz poszukiwanie rozwiązań problemów. Rola pracownika socjalnego jako mediatora ograniczona jest do słuchania stron, bez próby interwencji, 4) osiąganie porozumienia przez strony - ten etap cechuje się aktywnością mediatora, który

24 Tamże, s. 12.

25 I. Podobas, Mediacje..., dz. cyt., s. 157-159.

26 D. Rynkowska, M. Artymiak, Mediacje w pracy socjalnej, Wydawnictwo Uniwersytetu Rzeszowskiego, Rzeszów 2014, s. 103, 106. 
wskazuje stronom wypracowane przez nie sposoby rozwiązania konfliktu i informuje o możliwości ich realizacji w praktyce a także motywuje strony do dalszej współpracy, 5) zawieranie umowy - zakończenie procesu mediacji, obejmujące sporządzenie umowy dotyczącej współpracy stron w celu rozwiązania konfliktu. Powinno ono zawierać poszczególne warunki porozumienia, terminy ich realizacji oraz konsekwencje wynikające $z$ niedotrzymania ugody ${ }^{27}$. Jednocześnie, jak zauważa Paulina Bunio-Mroczek, mediacja w pracy socjalnej niekoniecznie wymaga pełnego procesu mediacyjnego i formalnego pełnienia przez pracownika socjalnego roli mediatora. Może on wykorzystywać ideę mediacji i wybrane elementy mediacji, łącząc je z pracą socjalną, zgodnie z założonymi celami ${ }^{28}$.

Pracownik socjalny wykorzystujący mediację w pracy socjalnej, powinien zachować przede wszystkim neutralność oraz bezstronność. Izabela Podobas, za I. Gójską, wymienia zadania mediatora, do których zalicza: ułatwienie komunikacji, pomoc w uświadamianiu praw każdej ze stron, stosowanie technik pomocnych podczas rozwiązywania sporu, formalne przewodniczenie sesjom mediacyjnym, eksploracja problemu, sprawdzanie realności propozycji, poszerzanie źródeł informacji poprzez kontakt z ekspertami, inicjowanie i kierowanie negocjacjami ${ }^{29}$. $\mathrm{Z}$ drugiej jednak strony autorka ta wskazuje na możliwość wykorzystania różnych rodzajów mediacji w pracy socjalnej. Odnosząc się do najczęściej stosowanej mediacji facylitatywnej (klasycznej), podkreśla, że w przypadku wielu spraw klientów pomocy społecznej ten rodzaj mediacji jest mniej przydatny, także z tego względu, że klienci pomocy społecznej często nie umieją wypracować sposobów rozwiązania konfliktu, nie są świadomi celu i istoty mediacji a także mogą częściej pojawiać się przeciwskazania do prowadzenia mediacji np. przemoc $\mathrm{w}$ rodzinie, uzależnienia. Często mediacja nie kończy się porozumieniem, nie daje także wzmocnienia żadnej ze stron konfliktu. Autorka zwraca uwagę na przydatność w pracy socjalnej mniej znanych i rzadziej wykorzystywanych w praktyce rodzajów mediacji: ewaluatywnej, transformatywnej, narracyjnej i humanistycznej. Stosowanie mediacji ewaluatywnych $\mathrm{w}$ mediacji socjalnej wiąże się z tym, że klienci pomocy społecznej często nie znają swoich praw oraz mogą mieć trudności z przedstawieniem własnych interesów. W tej grupie klientów może pojawić się oczekiwanie, że to właśnie mediator zasugeruje sposób rozwiązania. Autorka wskazuje także na możliwość zastosowania mediacji trasformatywnych, narracyjnych

27 A.W. Nocuń, J. Szmagalski, Podstawowe..., dz. cyt., s. 183-184, 187; D. Rynkowska, M. Artymiak, Mediacje..., dz. cyt., s. 111-112.

28 P. Bunio-Mroczek, Rodzaje..., dz. cyt., s. 20.

29 I. Podobas, Mediacje..., dz. cyt., s. 158. 
i humanistycznych, w których celem jest w dużej mierze poprawa relacji, zmiana i transformacja oraz dialog, na co właśnie w pracy socjalnej warto zwrócić uwagę ${ }^{30}$.

Wykorzystanie mediacji w pracy socjalnej niesie ze sobą wiele korzyści. Podstawową zaletą mediacji jest samodzielnie wypracowane przez strony porozumienie. W przypadku pracowników socjalnych stosujących mediację w pracy socjalnej korzyści przekładają się na realizację założonych celów pracy socjalnej i podnoszą jakość funkcjonowania klientów uwikłanych w konflikt $t^{31}$. Dla klientów pomocy społecznej mediacja stanowi szansę na uzyskanie poczucia poszanowania własnego stanowiska, co wiąże się ze wzmocnieniem godności klienta i poczucia pewności siebie. Mediacja pomaga zrozumieć siebie i drugą stronę. Korzyścią z porozumienia zawartego dzięki mediacji w pracy socjalnej jest także odzyskanie przez strony poczucia wpływu na rzeczywistośćc ${ }^{32}$. Zwraca się także uwagę, że mediacja zakończona sukcesem w postaci samodzielnie wypracowanego przez strony porozumienia, sprzyja kształtowaniu u klientów pomocy społecznej odpowiedzialności za swoje czyny ${ }^{33}$.

Odnosząc się do wykorzystania mediacji w pracy socjalnej nie można pominąć trudności w stosowaniu tej metody przez pracowników socjalnych. Wiążą się one z konfliktem ról pracownika socjalnego z rolą mediatora oraz oporem pracowników socjalnych przed narzucaniem im nowego zadania w postaci prowadzenia mediacji, a w konsekwencji konieczności zdobywania nowych umiejętności zawodowych. Barierą w stosowaniu mediacji może być także urzędniczy charakter zadań pracowników socjalnych, co utrudnia pogłębioną pracę z klientem w formie mediacji ${ }^{34}$. Występowanie trudności związanych z prowadzeniem mediacji w pracy socjalnej potwierdzają badania, przeprowadzone wśród pracowników socjalnych. Z badań Ewy Grudziewskiej i Agnieszki Lewickiej-Zelent ${ }^{35}$, Izabeli Podobas ${ }^{36}$ oraz Grażyny Mikołajczyk-Lerman ${ }^{37}$ wynika, że badani pracownicy mają ogólną

30 I. Podobas, Metody i style pracy mediatora $w$ obszarze mediacji socjalnych, w: Asystentura i mediacje socjalne, red. A. Durasiewicz, I. Podobas, Wyższa Szkoła Pedagogiczna im. Janusza Korczaka w Warszawie, Warszawa 2015, s. 31-40.

31 P. Bunio-Mroczek, Rodzaje..., dz. cyt., s. 19.

32 Tamże, s. 19-20.

33 D. Rynkowska, M. Artymiak, Mediacje..., dz. cyt., s. 114.

34 P. Bunio-Mroczek, Rodzaje..., dz. cyt., s. 20.

35 E. Grudziewska, Mediacja w percepcji pracowników socjalnych, w: E. Grudziewska, A. Lewicka-Zelent, Kompetencje mediacyjne w profesji pracownika socjalnego, Difin SA, Warszawa 2015, s. 74-92.

36 I. Podobas, Mediacje..., dz. cyt., s. 159-164.

37 G. Mikołajczyk-Lerman, Mediacja jako alternatywna forma rozwiazywania konfliktów rodzinnych $w$ opiniach pracowników instytucji pomocy społecznej z terenu 
wiedzę o mediacji, w większości nie mieli szkoleń z tego zakresu, jednak chcieliby brać w nich udział i uważają, że byłyby one przydatne w pracy socjalnej. Badania potwierdzają także, że pracownicy socjalni niezbyt często korzystają z mediacji jako metody pracy. Jako ograniczenia w wykorzystaniu mediacji w pracy socjalnej badani pracownicy socjalni wskazują na dwojakie trudności: związane z pracą zawodową i własnymi umiejętnościami zawodowymi oraz istniejące po stronie klientów. W pierwszej grupie mieści się brak czasu na stosowanie mediacji i pełne zdiagnozowanie problemu, nieznajomość zasad dotyczących procedury mediacyjnej i brak przepisów prawnych oraz brak umiejętności mediacyjnych i odpowiednich kwalifikacji. Druga grupa trudności odnosi się do braku chęci klientów do tego rodzaju wsparcia oraz braku ich zaangażowania. Utrudnieniem jest także mała świadomość społeczna klientów pomocy społecznej odnośnie celów mediacji i pozasądowych form rozwiązywania konfliktów ${ }^{38}$.

\section{Podsumowanie}

Mediacje wykorzystywane w pomocy społecznej sprzyjają realizacji celów pracy socjalnej. Mediacja, podobnie jak praca socjalna, pomaga ludziom w nabywaniu umiejętności rozwiązywania problemów, w tym przypadku konfliktów i zdolności do konstruktywnego radzenia sobie z nimi w różnych sytuacjach w przyszłości ${ }^{39}$. W mediacji proces ten wspiera bezstronny i neutralny mediator, ale to strony wypracowują korzystny obustronnie sposób rozwiązania konfliktu i ponoszą za niego odpowiedzialność. Mediacja jest więc zorientowana na współpracę i poszukiwanie wspólnych rozwiązań. Praktycznym wymiarem współdziałania stron staje się wypracowane, przy wsparciu bezstronnego mediatora, porozumienie. Niekiedy jednak sukces mediacji przejawia się już w samej możliwości wyraźnego wypowiedzenia przez stronę własnego stanowiska, stając się impulsem do zmiany.

W przypadku mediacji w pracy socjalnej korzyści z jej stosowania wydają się bardzo wyraziste. Jednak warto zadać sobie pytanie, kto powinien prowadzić mediacje socjalne i występować jako mediator. Kwestią otwartą pozostaje czy tej roli powinien podejmować się pracownik socjalny, prowadzący pracę socjalną $\mathrm{z}$ daną osobą lub rodziną, w której problemem są także konflikty np. rodzinne czy sąsiedzkie, czy zewnętrzny mediator. Prowadzenie mediacji wymaga zachowania przez mediatora bezstronności i neutralności a w wielu sytuacjach zawodowych,

województwa łódzkiego, „Zeszyty Pracy Socjalnej” 2016, z. 1, s. 6-9.

38 I. Podobas, Mediacje..., dz. cyt., s. 163.

39 B. Dubois, K.K. Miley, Praca socjalna..., dz. cyt., s. 29. 
z którymi spotyka się pracownik socjalny trudno zachować tę postawę ${ }^{40}$. Podobnie może dotyczyć to dobrowolności uczestnictwa stron w mediacji prowadzonej przez pracownika socjalnego. Przystąpienie do mediacji powinno być świadomą i autonomiczną decyzją stron, jednak w przypadku osób, z którymi pracownik socjalny prowadzi pracę socjalną nie można wykluczyć, że może ono wynikać z obawy przed potencjalną utratą świadczeń z pomocy społecznej w przypadku odmowy uczestnictwa w mediacji. Obawy klientów pomocy społecznej mogą także dotyczyć tego, czy mogą otwarcie mówić o wszystkich sprawach pracownikowi socjalnemu prowadzącemu mediacje. Mimo iż mediator zobowiązany jest do utrzymania w tajemnicy wszystkich informacji, które uzyskał w trakcie prowadzenia mediacji, można zakładać, że podopieczni będą w nim widzieć przede wszystkim przedstawiciela instytucji przyznającej świadczenia, co może skutkować brakiem szczerości w rozmowie. Trudność mediacji w pracy socjalnej może wiązać się także z brakiem możliwości zapewnienia przez pracownika socjalnego neutralnego miejsca, w którym prowadzona będzie mediacja, a także poświęcenia stronom odpowiedniej dla nich ilości czasu, który niekoniecznie musi przekładać się na pozytywny wynik mediacji w postaci porozumienia. W kontekście mediacji w pracy socjalnej warto także zwrócić uwagę na sytuacje, które są przeciwskazaniem dla prowadzenia mediacji m.in. przemoc w rodzinie, czy uzależnienie od alkoholu lub środków psychoaktywnych ${ }^{41}$, a które ustawowo należą do powodów udzielania pomocy społecznej ${ }^{42}$. Tym samym, aby efektywnie korzystać z mediacji w pracy socjalnej, pracownik socjalny musi mieć szeroką wiedzę o istocie i celach mediacji, jej rodzajach, procedurze postępowania mediacyjnego, ale także być świadomym sytuacji, gdy mediacja nie jest zalecana.

\section{Bibliografia}

Bargiel-Matusiewicz K., Negocjacje $i$ mediacje, Polskie Wydawnictwo Ekonomiczne, Warszawa 2010.

Bunio-Mroczek P., Rodzaje mediacji i ich rola w pracy socjalnej, „Zeszyty Pracy Socjalnej" 2016, z. 1.

Dubois B., Miley K.K., Praca socjalna. Zawód, który dodaje sił, t. 1, tł. K. Czekaj, Interart, Warszawa 1996.

40 Regionalny Ośrodek Polityki Społecznej w Krakowie, System..., s. 18.

41 A. Gójska, Mediacja w sprawach rodzinnych, Ministerstwo Sprawiedliwości, Warszawa 2011, s. 8.

42 Art. 7 Ustawa z dnia 12 marca 2004 r. o pomocy społecznej, dz. cyt. 
Duszka-Jakimko H., Alternatywne rozwiazywanie sporów prawnych na tle rozwojowego modelu prawa, w: Wokót praktycznych i teoretycznych aspektów komunikacji, red. P. Malinowski, H. Duszka-Jakimko, A. Suchorska, Uniwersytet Opolski, Kraków 2015.

Gmurzyńska E., Rodzaje mediacji, w: Mediacje. Teoria i praktyka, 2. wydanie rozszerzone, red. E. Gmurzyńska, R. Morek, Wolters Kluwer Polska Sp. z o.o., Warszawa 2014.

Gójska A., Mediacja w sprawach rodzinnych, Ministerstwo Sprawiedliwości, Warszawa 2011.

Grudziewska E., Mediacja w percepcji pracowników socjalnych, w: E. Grudziewska, A. Lewicka-Zelent, Kompetencje mediacyjne w profesji pracownika socjalnego, Difin SA, Warszawa 2015.

Kalisz A., Zienkiewicz A., Mediacja sadowa i pozasądowa. Zarys wyktadu, Wolters Kluwer Polska Sp. z o.o., Warszawa 2009.

Lewicka-Zelent A., Mediacja - podstawy teoretyczne, w: E. Grudziewska, A. Lewicka-Zelent, Kompetencje mediacyjne w profesji pracownika socjalnego, Difin SA, Warszawa 2015.

Mikołajczyk-Lerman G., Mediacja jako alternatywna forma rozwiazywania konfliktów rodzinnych $w$ opiniach pracowników instytucji pomocy społecznej z terenu województwa tódzkiego, „Zeszyty Pracy Socjalnej” 2016, z. 1.

Morek R., Wprowadzenie, w: Mediacje. Teoria i praktyka, red. E. Gmurzyńska, R. Morek, Wolters Kluwer Polska Sp. z o.o., Warszawa 2009.

Nocuń A.W., Szmagalski J., Podstawowe umiejętności w pracy socjalnej i ich ksztatcenie. Porozumiewanie się, rozwiazywanie problemów i konfliktów, Śląsk, Katowice 1998.

Pietrzyk A., Praca w zespole. Rozwiąywanie problemów i konfliktów grupowych, w: Praca socjalna wobec wspótczesnych problemów społecznych, red. S. Pawlas-Czyż, Wydawnictwo Edukacyjne Akapit, Toruń 2007.

Podobas I., Mediacje i negocjacje w pracy socjalnej, Centrum Rozwoju Zasobów Ludzkich, Warszawa 2014.

Podobas I., Metody i style pracy mediatora $w$ obszarze mediacji socjalnych, w: Asystentura i mediacje socjalne, red. A. Durasiewicz, I. Podobas, Wyższa Szkoła Pedagogiczna im. Janusza Korczaka w Warszawie, Warszawa 2015.

Regionalny Ośrodek Polityki Społecznej w Krakowie, System wspierania i formy pracy z rodzina, Kraków 2013.

Rękas A., Czy tylko sąd rozstrzygnie w sporze? Mediacja i sądownictwo polubowne, Ministerstwo Sprawiedliwości, Warszawa 2010.

Rynkowska D., Artymiak M., Mediacje w pracy socjalnej, Wydawnictwo Uniwersytetu Rzeszowskiego, Rzeszów 2014. 


\section{Akty prawne \\ Ustawa z dnia 12 marca 2004 r. o pomocy społecznej (Dz.U. 2004, nr 64, poz. 593). Ustawa z dnia 9 czerwca $2011 \mathrm{r}$. o wspieraniu rodziny i systemie pieczy zastępczej (Dz. U. 2011, nr 149, poz. 887). \\ Magda Urbańska: Mediation and exploiting them at the social work with the family}

\section{Summary}

Mediation is a process during which conflicted parties, helped by an impartial and neutral mediator, work out an agreement satisfactory to both parties. Mediation is used in various areas of family, business, civil and criminal matters. Moreover, it may be carried out in the area of social welfare and used in social work as a way to solve conflicts of the social welfare customers. The Act Concerning Family Support And Alternative Care Systems stipulates mediation as one of the forms of providing support to a family facing difficulties in fulfilling its childcare and upbringing functions. Mediation seems especially helpful in case of family conflicts of the customers. With support of the social worker as a mediator, the parties may not only work out an agreement advantageous for both parties, but also maintain or restore family relations. The paper shows the concept of mediation, types of mediation and how it can be used for social work. Social work mediation procedure was presented as well as benefits and difficulties attributable to mediation as a method of work with social welfare customers.

Key words: mediation, social work, social mediation 